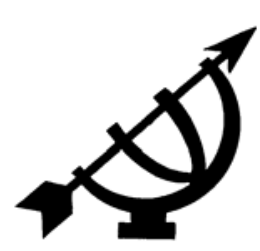

\title{
Metodologiese waarnemings by die meting van die beleefde lewensbeskoulike identiteit van 'n onderwysinstelling
}

H.J. Steyn, J.L. van der Walt \& C.F. Kirstein

Fakulteit Opvoedingswetenskappe

Potchefstroomkampus

Noordwes-Universiteit

POTCHEFSTROOM

E-pos: jlvdwalt@intekom.co.za

pokhjs@puk.ac.za

pokcfk@puk.ac.za

\begin{abstract}
Some methodological observations during a process of measuring the "experienced" life-conceptual identity of an educational institution
\end{abstract}

A project was launched by means of which it was hoped to establish to what extent the academic staff of a Faculty of Education at a South African university succeeded in actually living and experiencing the beliefs contained in their shared reformational view of life. This article is, however, neither a systematic report on the project itself nor of its findings. It rather focuses on some of the methodological problems that were encountered in the researchers' efforts to apply quantitative research procedures to measuring a life-concept as a theoretical construct. It is concluded that such procedures should be augmented with qualitative research methods. Several other methodological measures are recommended for increasing the chances of success in a project of this nature.

\section{Opsomming}

Metodologiese waarnemings by die meting van die beleefde lewensbeskoulike identiteit van 'n onderwysinstelling

'n Projek is van stapel gestuur waarmee beoog is om te bepaal tot watter mate die akademiese personeel van 'n Opvoedkundefakulteit aan 'n Suid-Afrikaanse universiteit daarin slaag om die 
oortuigings ingebed in hulle gedeelde reformatoriese lewensvisie werklik uit te leef in hulle akademiese werk. Hierdie artikel is egter nie 'n sistematiese verslag oor die ondersoek of die resultate daarvan nie. Die artikel is gefokus op enkele van die navorsingsmetodologiese probleme wat die ondersoekers op die lyf geloop het in hulle pogings om kwantitatiewe navorsingsprosedures toe te pas op die meting van die lewensvisie as 'n teoretiese konstruk. Die navorsers kom tot die konklusie dat sulke prosedures aangevul moet word deur kwalitatiewe ondersoekmetodes. Verskeie ander metodologiese ingrepe word aan die hand gedoen ten einde die kanse op welslae met so 'n ondersoekprojek te verbeter.

\section{Inleiding en probleemstelling}

Tussen 2001 en 2004 is daar 'n ondersoek uitgevoer in die Fakulteit Opvoedingswetenskappe van die Noordwes-Universiteit (Potchefstroomse kampus), waarin gepoog is om die be-leefde lewensbeskoulike identiteit van die akademiese personeel in die Fakulteit te "meet" of te bepaal. Met ander woorde, die ondersoek het ten doel gehad om vas te stel tot welke mate die akademiese personeel van die Fakulteit daarin slaag om enersyds die lewensbeskoulike karakter van die Universiteit as onderwysinstelling, dié van die Fakulteit as onderdeel van die Universiteit ${ }^{1}$ en ook hulle persoonlike lewensvisie tot praktyk te maak in hulle daaglikse akademiese werksaamhede.

Die ondersoek het in die volgende vyf fases verloop:

- die uitstuur aan akademiese personeel van 'n kort samevatting van 'n reformatoriese lewensvisie met die oog op bestudering en praktykmaking waar moontlik;

- die invul van 'n kort vraelys (oop vrae) waarin die betrokke personeellid self kon aandui hoedat hy/sy 'n reformatoriese lewensvisie tot uitdrukking bring in sy/haar akademiese praktyk;

$1 \quad$ Vir die doeleindes van hierdie ondersoek is die Fakulteit self, hoewel dit deel van die universiteit is, as 'n onderwysinstelling beskou. Volgens die Verklarende Handwoordeboek van die Afrikaanse taal (Odendal et al., 1997) beteken die woord instelling onder meer iets wat ingestel is met 'n eie werking en doel. Die Cambridge International Dictionary of English (Procter, 2002) en die Oxford Advanced Learner's Dictionary (Wehmeier, 2002) maak albei voorsiening vir die betekenis van institution aangegee deur die Greenwich English Dictionary (Patterson, 1990), naamlik as "something instituted". 'n Fakulteit is ook ingestel met 'n bepaalde doel en organisasie. 
- 'n soortgelyke vraelys aan die studente ten einde te bepaal wat hulle persepsies is in verband met die mate waarin hulle dosente daarin slaag om 'n reformatoriese lewensvisie in die praktyk tot sy reg te laat kom;

- hierna is die ondersoek herhaal met 'n vraelys (5-puntskaal) aan akademiese personeellede en studente; en

- fokusgroeponderhoude is gevoer met akademiese personeellede en studentegroepe.

Die doel van hierdie artikel is nie om te rapporteer oor die verloop van die ondersoek of oor die resultate daarvan nie. Die doel is om enkele waarnemings deur te gee ten aansien van metodologiese aspekte en vraagstukke wat betrokke is by die "meting" van die beleefde lewensbeskoulike identiteit van die akademiese personeel van 'n onderwysinstelling. Die ondersoek wat uitgevoer is, het aan die lig gebring dat daar heelwat navorsingsmetodologiese vraagstukke is wat nadere besinning verdien. Besinning is nodig sodat navorsers wat soortgelyke projekte wil uitvoer, die probleme doeltreffend kan vermy in hulle projekbeplanning.

\section{Kontekstualisering van die ondersoek}

Dit is nie gebruiklik vir 'n onderwysinstelling, of vir die onderdele daarvan, om te besin oor die lewensbeskoulike karakter of identiteit daarvan nie. Weens die gedagte van onderwysversuiling 2 in Nederland kom dit in daardie land meer voor (Hoeksema, 1992; Klink, 1992; Sturm et al., 1998). Dit is ook meer gebruiklik in onafhanklike instellings soos die bekende universiteitskolleges in Noord-Amerika (Dordt, Calvin, Institute of Christian Studies en andere) en in Nederland (vgl. De Muynck, 2004) en sogenaamde privaatskole (vgl. Van der Kooy, 2004). In Suid-Afrika is die voormalige Potchefstroomse Universiteit vir Christelike Hoër Onderwys (PU vir $\mathrm{CHO}$ ) 'n noemenswaardige uitsondering in die tersiêre onderwyssektor. Dié Universiteit het tot en met die samesmeltingsooreenkoms in 2004 altyd openlik bekend gestaan as 'n "karakter-universiteit". Die Christelike (reformatoriese) lewens-

2 Die term versuiling verwys na 'n gebruik wat aan die begin van die vorige eeu in Nederland ontstaan het ingevolge waarvan skole, koerante, organisasies, radioen televisiestasies en dies meer hulleself byeen kon skaar as 'n lewensbeskoulik identifiseerbare groep of suil (pilaar). Op hierdie manier het daar 'n hele aantal lewensbeskoulike suile of pilare in die Nederlandse samelewing ontstaan, en daar is gepraat van versuiling van die samelewing. 
beskoulike identiteit daarvan was altyd op die een of ander manier herkenbaar. Voor die samesmelting met die voormalige NoordwesUniversiteit in Mafikeng in 2004 om die nuwe Noordwes-Universiteit te vorm, het die $\mathrm{PU}$ vir $\mathrm{CHO}$ sy lewensbeskoulike karakter tot uitdrukking laat kom in die vorm van sy slagspreuk (In U Lig), sy visie en missie en 'n konstante stroom beleids- en bestuursdokumente. Die hersiening van al hierdie dokumente is tans hoog op die agenda van die nuwe Universiteit.

In 2001 het die voormalige Potchefstroomse Onderwyskollege (POK, wat in 1919 opgerig is) en die destydse Fakulteit Opvoedkunde van die PU vir CHO (wat in 1945 tot stand gekom het) saamgesmelt om 'n nuwe Fakulteit Opvoedingswetenskappe te vorm. Dit is tans ' $n$ fakulteit van die nuwe Noordwes-Universiteit. Na die ontstaan van die nuwe Universiteit was sowel die lewensbeskoulike karakter as die beleidsdokumente van die voormalige PU vir $\mathrm{CHO}$ voorlopig nog steeds van toepassing op die Fakulteit. Tot op die datum wat hierdie artikel geskryf is, het die lewensbeskoulike karakter van die Potchefstroomkampus van die nuwe Universiteit nog nie noemenswaardig verander nie; op daardie kampus kan reformatoriese lewensbeskoulike waardes voorasnog uitgeleef word.

Volgens die beleids- en bestuursdokumente wat in 2001-2004 van krag was, moes bestuurders toesien dat akademiese personeel die nodige aandag gee aan die (vak)filosofiese grondslae van hulle onderskeie vakwetenskappe. Weens die nuutheid van die Fakulteit Opvoedingswetenskappe, wat in 2001 tot stand gekom het, is daar vir die doeleindes van hierdie projek besluit om slegs vas te stel tot watter mate die akademiese personeel daarin slaag om die lewensvisie wat gangbaar is in die Fakulteit en op daardie stadium herkenbaar reformatories van aard was, tot praktyk te maak in hulle daaglikse werksaamhede. 3 Daar is dus 'n doelbewuste besluit geneem om op daardie stadium nie te poog om vas te stel tot welke mate hulle daarin slaag om ook die teoretiese grondslae, die vakfilosofiese en wetenskapsfilosofiese vraagstukke van hulle dissiplines te ontwikkel en te beheers nie. Anders gestel, daar is besluit om slegs op die "be-leefde lewensbeskoulike identiteit" van die akademiese personeel te fokus.

3 Die akademiese personeel was op daardie stadium feitlik nog almal afkomstig uit die voormalige Fakulteit Opvoedkunde van die $\mathrm{PU}$ vir $\mathrm{CHO}$ en die voormalige POK. 
Volgens die tersaaklike beleids- en bestuursdokumente van die Universiteit (PU vir CHO, 2001; PU vir CHO, 2002; Potgieter, 2002; $\mathrm{PU}$ vir CHO, 2003) rus daar 'n taak en plig op die skouers van akademiese bestuurders om toe te sien dat akademiese personeel aandag gee aan sulke teoretiese en voorteoretiese aspekte (insluitende die lewensvisie) in hulle wetenskaplike arbeid. In een van die vermelde dokumente word hierdie verpligting pertinent soos volg gestel: "In alle programme sal vir toepaslike filosofiese en etiese kwessies gekurrikuleer word en programbestuurders sal verantwoordelik gehou word vir gestelde uitkomste" (PU vir $\mathrm{CHO}$, 2002). In 'n bylaag tot die dokument is 'n aantal vrae geformuleer met die oog op die beoordeling van die werksuitsette van bestuurshoofde (viserektore, dekane en direkteure van akademiese programme). Die vrae hou verband met die volgende verpligtings (take) wat op bestuurders se skouers rus:

1. Ontwikkeling van die filosofiese en etiese dimensies van die wetenskap in onderrigleer en navorsing.

1.1 Akademiese personeel sal bemagtig word om vakfilosofiese en etiese kwessies in hulle onderrig- en navorsingswerk, benewens ander filosofiese uitgangspunte, volgens die grondslag van die universiteit te hanteer.

1.2 In alle programme sal toepaslike filosofiese en etiese kwessies gekurrikuleer word en programbestuurders sal verantwoordelik gehou word vir die gestelde uitkomste.

Die kritieke uitkomste vir die onderrig van studente, soos deur die Senaat van die Universiteit aanvaar, het die grondslag gelê, aldus Potgieter (2002), vir 'n geïntegreerde benadering tot wetenskapsbeoefening. Aangesien daar voorsiening gemaak word vir uitkomste wat met die Universiteit se opvoedings- en wetenskapsbeskouing te doen het, word dit van fakulteite en skole vereis om dié soort vakfilosofiese en etiese problematiek in hulle onderrigprogramme aan die orde te stel, sodat studente in aanraking gebring kan word met die Christelike denktradisie in sy/haar vakgebied.

'n Ondersoekprosedure moes dus uitgewerk word om te bepaal of die akademiese personeel van die Fakulteit Opvoedingswetenskappe wel aan hierdie taak aandag gee en tot welke mate hulle daarin welslae behaal. In beginsel is meting van die sukses van die uitvoering van hierdie bestuurstaak moontlik, aangesien die taak 
enersyds geoperasionaliseer 4 is in beleidsdokumente, en andersyds geoperasionaliseer is in die vorm van die kritieke onderriguitkomste waarna hierbo verwys is (vgl. Du Plessis, 1993:91).

\section{Be-leefde lewensbeskoulike identiteit}

Daar bestaan verskeie definisies van 'n lewens- en wêreldbeskouing. Een van die bruikbaarste vanweë die bondigheid en pittigheid daarvan, is dié van Taljaard (1976:8): "Dit ['n lewens- en wêreldbeskouing] is ' $n$ stel fundamentele oortuiginge aangaande God (of 'n beginsel wat in die plek van God gestel word), die werklikheid, die wette waaraan die werklikheid onderworpe is, en die samehang tussen hierdie drie groothede." Van der Walt (2001:13) gee ook 'n kort definisie: "Basically a worldview describes our understanding of reality and our place and task in creation."

Die lewensvisie het te doen met die mees basiese vrae wat die mens oor die lewe en die menslike bestaan stel. Dit sluit antwoorde op die volgende vier (stelle) vrae in (Colson, 2001:xvii-xviii, 19, 297; vgl. ook Middleton \& Walsh, 1995:11):

- Waar kom ons vandaan, en wie is ons?

- Wat het met die wêreld/die werklikheid gebeur en wat het alles skeefgeloop? Wat is die menslike dilemma?

- Wat kan ons doen om hierdie probleme/dilemma reg te stel?

- Hoe kan ons ons lewensvisie ten volle uitleef? Hoe kan die manier waarop ons die wêreld en die werklikheid sien ons lei om die huidige stand van sake te verander?

Lambert (1997:154) voeg nog die volgende vrae by:

- Waarheen is ek op pad?

- Waaroor gaan dit in die lewe?

- Hoe kan ek gelukkig leef en sterf?

- Is daar 'n god?

Volgens Van der Walt (2001:13-17) bestaan 'n Bybelse (reformatoriese) werklikheidsvisie uit die volgende komponente:

4 Tot uitdrukking gebring, gekonkretiseer is. 
- 'n opvatting of siening aangaande God of iemand of iets anders wat as goddelik beskou word;

- aangaande die wet, orde en waardes;

- aangaande die betekenis van menswees;

- aangaande die ideale samelewing;

- aangaande ons verhouding met die natuur; en

- aangaande tyd en die geskiedenis.

In die geval van 'n reformatoriese denkraamwerk word hierdie vrae vanuit 'n Bybelsgefundeerde standpunt beantwoord. Die eerste vraag hierbo het byvoorbeeld te doen met die skeppingsmotief, die tweede met die sondeval, die derde met herstel in Jesus Christus, en die vierde met die herstel van die kulturele omgewing waarin die mens hom/haar bevind.

Die mens se lewens- en wêreldbeskouing help hom/haar om sin te maak van die omgewing (Pudlas, 1997:171). Alle mense, dus ook mense betrokke by die akademie, stel die vrae wat hierbo gestel is. Hulle vind die antwoorde in hulle persoonlike geloof (geloofsoortuigings) en in hul visie op die werklikheid. Meestal is die uiteindelike stilswyende antwoorde deel van 'n mens se geloof, eerder as dat hulle doelbewus tot stand kom deur 'n rasionele ondersoek. Menslike gedrag, dus ook dié van die akademiese personeellid of beoefenaar van die wetenskap, neig om konsistent met die werklikheidsvisie te wees.

Bakker (2004:21) tref 'n onderskeid wat vir hierdie ondersoek van belang was. Opvoedings- en onderwysinstellings besin dikwels op formele wyse oor hulle lewensbeskoulike identiteit. Hierdie besinning vind egter in 'n "ander" taal plaas: in plaas daarvan om te praat van die "identiteit van die instelling" of die "Christelike identiteit van die instelling" word gepraat in terme van die visie en die missie van die instelling, die instelling as waardegemeenskap, oor die kernwaardes daarvan, of die profilering van die instelling. Die neerslag van sodanige besinning aan die voormalige $\mathrm{PU}$ vir $\mathrm{CHO}$ is in afdeling 2 hierbo, met verwysing na beleidsdokumente, weergegee.

Dit het in hierdie ondersoek egter nie oor hierdie formele sy van die lewensbeskoulike (Christelike, reformatoriese) identiteit gegaan nie, maar wel oor dit wat Bakker beleefde lewensbeskoulike identiteit noem. Toegepas op die situasie in die Fakulteit Opvoedingswetenskappe van die Noordwes-Universiteit (Potchefstroomkampus), is 
die vraag dus nie of die akademiese personeellede die inhoud van die beleidsdokumente formeel verstaan en aanvaarbaar vind nie, maar of hulle uit eie praktyk kan aantoon hoedat die lewensbeskoulike identiteit van die Fakulteit tot individuele, konkrete uitdrukking kom. In dié proses moes dit onder meer duidelik word dat in die opstelling van studiegidse, die keuse van handboeke, die interaksie met die studente en ander aspekte van die professionele praktyk van die akademiese personeellid die formele identiteit van die Universiteit en die Fakulteit wel in die praktyk tot uitdrukking (kan) kom. Die volgende tipe vrae is aan akademiese personeellede gevra: Hoekom het jy 'n akademiese personeellid in die Fakulteit geword? Wat, in lewensbeskoulike terme, trek jou aan ten opsigte van die Fakulteit? Wat is vir jou betekenisvol in die werk wat jy doen? Waarom doen jy die werk wat jy doen?

Dit gaan dus oor die verskil tussen 'n blote refleksie oor die formele lewensbeskoulike identiteit van die Fakulteit en die daaglikse belewing en vormgewing van die identiteit en die daarby passende sinbelewing. Volgens Bakker (2004:11) kan dit nie sonder meer aanvaar word dat (in hierdie geval) akademiese personeel die formele besinning oor lewensbeskoulike identiteit (lewensbeskoulike oriëntasie van die Fakulteit) logies en konsekwent in die werkspraktyk kan verwesenlik of vorm gee nie. Die sinbelewing van akademiese personeel vind elders plaas as daar waar die formele refleksie plaasvind oor die lewensbeskoulike identiteit van die onderwysinstelling. As 'n mens dus wil weet of gestalte gegee word aan die lewensbeskoulike identiteit van die Fakulteit (vorm gegee word) moet 'n mens konsentreer op die vlak van die akademiese personeellid se sinbelewing. Volgens Bakker (2004:16) het ons hier met twee kante te doen:

... aan de ene kant ... formele identiteit, deductief redeneren, 'smalle' identiteitsperceptie ... (en) aan de andere kant inductief en contextueel denken ...

Die akademiese personeellid bevind hom/haar in die praktyk aan laasgenoemde kant.

Na Bakker (2004:16) se mening is die klimaat in onderwysinstellinge tans meer gunstig as ooit om 'n gesprek te voer oor die lewensbeskoulike identiteit daarvan,

... maar dan graag wel aan gene zijde van de kloof, daar waar het gaat om de beleefde identiteit van de (onderwijsinstelling) en de creatieve betrokkenheid daarbij bij de individuele leerkracht. 


\section{Beleefde lewensbeskoulike identiteit as teoretiese konstruk}

Die begrippe lewensbeskouing, lewensvisie en beleefde lewensbeskoulike identiteit verwys na teoretiese konstrukte. Die aard en omvang daarvan moet dus afgelei word uit die gedrag, optrede of woorde van mense. 'n Teoretiese konstruk verwys na iets wat nie regstreeks waargeneem of gemeet kan word nie, maar wat uit sekere indikatore afgelei moet word (Leedy \& Ormrod, 2001:98-99). Volgens Jaeger (1988:326-327) kan 'n konstruk selfs beskryf word as 'n gekonstrueerde veranderlike wat nie observeerbaar is nie. Die term konstruk is as 't ware 'n etiket wat geheg word aan 'n konsekwente stel (consistent set) ander waarneembare gedragsvorme of -patrone. As 'n mens dus gevolgtrekkings daaroor wil maak, moet die navorser veralgemeen vanaf respondente se respons, gedrag of houdings na die betrokke respondente se standpunte of houdings oor die konstruk "beleefde lewensbeskoulike identiteit". Deur so te werk te gaan, gaan die ondersoeker van die veronderstelling uit dat die vrae wat hy/sy stel inderdaad die regte gedrag, optrede of houdings van die respondente meet, en dit ook toereikend doen, en dat die meetinstrument (die items daarin) gepas is vir die teorie waardeur die konstruk in die eerste plek beskryf of gedefinieer is. Hierdie gepastheid en toereikendheid is van kritieke belang vir die konstrukgeldigheid van die instrument.

Die feit dat die uitdrukking beleefde lewensbeskoulike identiteit verwys na 'n teoretiese konstruk, het die ondersoekers voor 'n aantal ernstige metodologiese probleme geplaas.

\section{Enkele metodologiese oorwegings en stappe}

\subsection{Lewensvisie as teoretiese konstruk}

Die term lewensvisie verwys, soos hierbo reeds aangetoon is, na 'n verskynsel wat enersyds taamlik maklik omskryf en selfs gedefinieer kan word. Tegelyk, egter, verwys dit na 'n uiters ingewikkelde en omvattende verskynsel, wat nie slegs in algemene terme moeilik verwoord word nie, maar ook feitlik enige poging tot veralgemening tot mislukking doem. Hoewel sekere kenmerke van lewensvisies aangeteken kan word, en hoewel die rol en funksies van die lewensvisie in die mens se lewe bepaal en verwoord kan word, is dit ' $n$ feitlik onbegonne taak om persoon $X$ of persoon $Y$ se lewensvisie te verwoord. Die metodologiese vraag was dus: wat gebruik 'n mens as kriterium of norm by die meting van die praktykmaking of die belewing van 'n lewensvisie? Daar bestaan inderdaad geen 
bloudruk vir die term lewensvisie nie, juis omdat die lewensvisie so persoonlik, individueel-uniek van elke persoon is en so radikaal en integraal deel vorm van sy/haar persoonlikheid (Van der Walt, 1994:39).

Vir die doel van die ondersoek is daar tog 'n poging aangewend om 'n "kort begrip" van 'n reformatoriese lewensvisie te formuleer. Dit het egter uit die response van veral die akademiese personeel (nie in dieselfde mate by die studente nie) geblyk dat hulle dié poging maar net as een van baie formulerings beskou het, en dat dit nie juis as ' $n$ weerspieëling van personeellid $X$ of $Y$ se eie lewensvisie beskou is nie. Die ondersoekers het hierdie afleiding uit die response gemaak, ondanks die feit dat die "kort begrip" telkens in meer verfynde konsepvorm onder die akademiese personeel versprei is vir kommentaar. Terugskouend sou 'n mens kon sê dat die akademiese personeel 'n houding ingeneem het van: Ja, daar is niks verkeerd met hierdie formulering van 'n reformatoriese lewensvisie nie, maar dit is nie my lewensvisie nie! Dit is hoogstens 'n formele, akademiese poging! Op hierdie punt het die ondersoek dus al met 'n ernstige probleem te doen gekry.

\subsection{Wie se lewensvisie?}

Weens die teenwoordigheid van allerlei magsverhoudinge in 'n onderwysinstelling soos 'n fakulteit van opvoedkunde, is die vraag inderdaad onder akademiese personeel gestel: Wie se lewensvisie is hier kortliks saamgevat? Die akademiese antwoord op hierdie vraag is voor die hand liggend: Niemand s' $n$ nie; dit is 'n akademieswetenskaplike poging om 'n reformatoriese lewensvisie te formuleer. Die traagheid van akademiese personeel om byvoorbeeld op vraelyste na aanleiding van hierdie kort formulering van die lewensvisie te reageer, is miskien 'n aanduiding van die feit dat akademiese personeel hierdie antwoord nie oortuigend gevind het nie. Soos hierbo aangedui, is die toesig oor die mate waartoe akademiese personeel daarin slaag om teoretiese en voorteoretiese grondslae van hulle wetenskappe na te gaan en uit te werk 'n bestuurstaak van die dekane en die direkteure van akademiese programme. Die vermelde kort samevatting van 'n reformatoriese lewensvisie is dus moontlik daarvan "verdink" dat dit 'n weerspieëling is van die lewensvisie van die maghebbers in die Fakulteit. Metodologies gesproke, was die navorsers dus gekonfronteer met ' $n$ ernstige houdings- of gesindheidsprobleem onder die potensiële respondente. Weens hierdie probleem het slegs 37 uit 'n moontlike 66 respondente in die eerste rondte vraelyste ingevul. In die tweede rondte het slegs 34 uit 'n moontlike 96 
respondente (die Fakulteit het intussen groter geword) gereageer op die versoek om die vraelyste in te vul.

\subsection{Die lewensvisie of ' $n$ lewensvisie}

Toe die projek in 2001 in sy beplanningsfase was, het die vraag opgeduik: moet die belewing en praktykmaking van die of 'n (reformatoriese) lewensvisie getoets of gemeet word? Voor die aanbreek van die nuwe grondwetlike bedeling in die Republiek van Suid-Afrika in 1996, sou 'n mens kon beweer dat die akademiese personeel van die $\mathrm{PU}$ vir $\mathrm{CHO}$ breedweg dieselfde reformatoriese lewensvisie met mekaar gedeel het. Dit kan toegeskryf word aan die feit dat alle akademiese personeel by aanstelling streng keuring ondergaan het, onder meer ook wat hulle lewensvisie en die uitlewing daarvan betref - selfs in terme van kerklike meelewing. $\mathrm{Na}$ die aanbreek van die nuwe grondwetlike bedeling in 1996 was hierdie soort toets van die baan en het allerlei menseregte en -vryhede gegeld: vryheid van godsdiens en oortuiging en van mening en spraak, om maar enkeles te noem.

Om dié probleem te omseil is besluit om 'n reformatoriese lewensvisie kortliks te formuleer en onder alle personeel te versprei vir kommentaar. Soos reeds hierbo vermeld, is hierdie pogings taamlik onverskillig ontvang, waarskynlik omdat die akademiese personeel hulle nie eksistensieel daarmee kon vereenselwig nie: die samevattings is nie verkeerd of foutief nie, maar dit bly 'n onpersoonlike akademiese poging deur die bestuur van die Fakulteit.

\subsection{Mag so 'n ondersoek nog uitgevoer word in die konteks van die nuwe universiteit?}

In die lig van die feit dat die $\mathrm{PU}$ vir $\mathrm{CHO}$ deel geword het van 'n nuwe universiteit het die vraag lateraan na vore gekom of dit nog van akademiese personeel verwag kan word om die/'n reformatoriese lewensvisie tot praktyk te maak in hulle alledaagse werk. Hoewel die Potchefstroomkampus van die nuwe universiteit nog 'n eie waardestelsel kan handhaaf en uitleef, is hierdie 'n problematiese saak in die lig van akademiese personeel en studente se grondwetlike reg op vryheid van godsdiens, mening en spraak. Dit kan dus nie sonder meer deur bestuurders verwag word dat 'n bepaalde lewensvisie, soos die (of 'n) reformatoriese lewensvisie, deur akademiese personeel tot praktyk gemaak behoort te word nie. Sowel die akademiese personeellid as die student het die reg tot vryheid van spraak en mening - wat ook in die akademiese situasie 
uitgeleef behoort te kan word, dog sonder die benadeling van die grondwetlike regte en vryhede van andere.

Metodologies gesproke, het hierdie toedrag van sake ook die ondersoek bemoeilik. Weens die vermelde houdings- of gesindheidsprobleem onder die akademiese personeel kon hulle ook geredeneer het dat hulle nie in die nuwe grondwetlike en universitêre bedeling nodig het om die vraelyste in te vul nie. Anders gestel: dit wil voorkom of die verbintenis (commitment) wat daar voor, argumentshalwe 1996 se nuwe grondwetlike bedeling in die land, onder akademiese personeel van die $\mathrm{PU}$ vir $\mathrm{CHO}$ bestaan het om 'n Bybelsgefundeerde (reformatoriese) lewensvisie tot praktyk te maak (be-leefde lewensvisie), grotendeels verdwyn het. Dit wil dus voorkom of dit sedert 1996 aan die voormalige PU vir $\mathrm{CHO}$ en sedert die aanvang van 2004 met die aanbreek van die nuwe Noordwes-Universiteit "business as usual" aan die universiteit begin word het, sonder die pertinente en herkenbare lewensbeskoulike commitment van voor 1996.

\subsection{Kwantitatief versus kwalitatief}

Omdat beleefde lewensvisie 'n moeilik meetbare konstruk is, was dit 'n uitdaging om 'n kwantitatiewe navorsingsprosedure daarvoor te ontwikkel. 'n Literatuurondersoek het aan die lig gebring dat daar nie presedente vir so 'n ondersoek bestaan nie. Die vraelyste opgestel deur Francis $(1984 ; 1985)$ onder die titel Christian beliefs inventory het belowend gelyk as instrument, maar was nie heeltemal gepas nie, aangesien dit kerklik (Anglikaans) gerig was. Dieselfde geld die vraelys wat opgestel is deur Rijken-Hoevens (s.a.) onder die titel $E r$ ziin nog katechisanten - dit was meer gerig op reformatoriese kerke. $\mathrm{Na}$ ondersoek en oorweging is besluit om die werkwyse te volg wat Van Driel en Kole (1987:48) beskryf het in hulle ondersoek na die "educatief climaat" in kerklike gemeentes: die toepassing van 'n mengsel van kwantitatiewe en kwalitatiewe prosedures. Omdat geen gepaste vraelys gevind kon word nie, moes een self ontwerp word.

Die konstrukgeldigheid van die vraelys(te) is verseker deurdat die drie navorsers oor 'n tydperk van ongeveer drie maande gewerk het aan die formulering van 'n reformatoriese lewensvisie. Hulle het die resultaat van hulle werk herhaaldelik aan die akademiese personeel voorgelê vir kommentaar. (Soos egter vermeld, was die terugvoering meestal gering.) Hierna is 'n vraelys met oop items ontwikkel. Elke item was 'n operasioneling (formulering) van 'n kernstelling uit die voorheen geformuleerde reformatoriese lewensvisie wat die akademiese personeel na veronderstelling reeds bestudeer het. Die 
konstrukgeldigheid van die meetinstrument is verhoog deurdat die drie navorsers onafhanklik van mekaar nie net die items opgestel het nie, maar ook elkeen onafhanklik die response beoordeel het. Elke beoordelaar het 'n respons op 'n skaal van 0 tot 5 volgens ooreengekome norme beoordeel. Die drie beoordelingspunte is bymekaar gevoeg, en 'n gemiddeld vir elke item per respondent bereken. Op hierdie manier is gevind dat die respondente 'n totaalgemiddeld van 70 persent behaal het. Dus het die respondente volgens hierdie instrument op 'n vlak van 70 persent daarin geslaag om 'n reformatoriese lewensvisie tot praktyk te maak in hulle alledaagse werk. 5

'n Soortgelyke vraelys aan studente (bereikbare steekproef: $n=94$ ) is op soortgelyke wyse uitgewerk ten einde konstrukgeldigheid te verseker. In hierdie geval moes die respondente reageer op 'n Likert-tipe 5-puntskaal, waar hulle moes aandui of hulle dosente "altyd of heeltemal" tot "heeltemal nooit of glad nie" aandag gee aan die praktykmaking van die reformatoriese lewensbeskouing. Die response is rekenaarmatig nagesien, en 'n persentasie van $76 \%$ is opgelewer. Volgens die rasionaal wat vir hierdie proses uitgewerk is, het dit daarop neergekom dat hierdie groep studente van oordeel was dat hulle dosente tot ' $n$ vlak van ongeveer $76 \%$ aandag gee aan die praktykmaking van 'n reformatoriese lewensvisie. Dit klop tot 'n hoë mate met die vlak van $70 \%$ wat die akademiese personeel behaal het.

Terugvoering is aan die personeel gegee oor hierdie bevindinge. Op grond van die kommentaar wat ingewin is, is vraelyste met soortgelyke items (inhoudelik; 5-puntskaal) in die tweede rondte aan sowel die akademiese personeel as die studente voorgelê. In hierdie geval het 34 uit 'n potensiële 96 personeel-respondente en 'n totaal (die bereikbare steekproef) van 369 studente aan die proses deelgeneem. Die Cronbach-alpha-betroubaarheidskoëffisiënt (vgl. Breakwell et al., 1995:205) van hierdie vraelyste was onderskeidelik 0.88 (personeel) en 0.89 (studente). Die resultate van albei vraelyste toon dat sowel die akademiese personeel, volgens hulle eie oordeel, asook dié van hulle studente, se aandag aan 'n reformatoriese lewensvisie hoofsaaklik in die kategorieë val van "akademiese personeel gee deurlopend, aandag aan die praktykmaking van hierdie element van 'n reformatoriese lewensvisie", of $(\mathrm{N}=37$ uit ' $\mathrm{n}$ moontlike 66 ) en kan nie na al die personeel veralgemeen word nie. 
hulle gee nou en dan, waar dit relevant is, daaraan aandag. Omdat die studentegroep vier keer so groot was as in die eerste rondte, was hulle terugvoering oor die beleefde lewensvisie van hulle dosente nie so gunstig soos in die eerste rondte nie (gekwantifiseer op die vlak van $56 \%)$.

Omdat die effektiwiteit van al hierdie kwantitatiewe ondersoekprosedures die hele tyd by die navorsers sowel as by die respondente onder ' $n$ mate van verdenking was, is besluit om die kwantitatiewe bevindings aan te vul met kwalitatiewe prosedures. Vir hierdie doel is vyf fokusgroeponderhoude (5 lede per groep) gevoer oor die items in die laaste twee vraelyste (vgl. Leedy \& Ormrod, 2001:159 e.v.). Onderhoude is gevoer met onervare personeel, meer ervare en senior personeel, baie senior personeel, insluitende direkteure van skole en programme, tweedejaar- en vierdejaarstudente. Hierdie onderhoude het die kwantitatiewe bevindings bevestig, naamlik dat die personeel in die Fakulteit Opvoedingswetenskappe aan die Potchefstroomkampus van die nuwe Noordwes-Universiteit tot 'n hoë mate aandag gee aan hulle be-leefde reformatoriese lewensvisie, dit wil sê aan die praktykmaking daarvan. Daar is egter ook nog heelwat ruimte vir verbetering op verskeie vlakke.

\section{Algemene bevindings}

Die bevindings na aanleiding van die ondersoek, kwantitatief sowel as kwalitatief, is soos volg:

- Alle akademiese personeel verkeer nie onder die besef dat dit een van die bestuursverantwoordelikhede van dekane en direkteure is om seker te maak dat die lewensvisie van akademiese personeel wel op die een of ander manier in die praktyk tot vergestalting behoort te kom nie - dit behoort dus 'n "beleefde lewensvisie" te word.

- Die gemiddelde vlak van praktykmaking van die reformatoriese lewensvisie deur akademiese personeellede in die eerste rondte was goed. Ook die studente het in die eerste rondte van die ondersoek geoordeel dat hulle dosente goed presteer wat die praktykmaking van hulle lewensvisie betref. Die studentesteekproef, wat in die tweede rondte byna vier keer groter was, het egter getoon dat die prentjie nie heeltemal so gunstig is nie. Dit wil voorkom of daar heelwat ruimte vir verbetering is in die praktykmaking of belewing van akademiese personeel se lewensvisie, te oordeel aan die terugvoering van hulle studente. 
- Die fokusgroeponderhoude het getoon dat feitlik al die akademiese personeel ten minste 'n deeglike poging aanwend om hulle lewensvisie tot praktyk te maak. Al die pogings is nie ewe geslaagd nie, en daar is dus ruimte vir verbetering en verdere toerusting. Opvoedkunde- en Grondslagfasedosente slaag die beste in praktykmaking of be-lewing van 'n reformatoriese lewensvisie.

- Die ondersoek het bevestig dat, hoewel dit belangrik is om te besin oor die formele lewensbeskoulike identiteit of karakter van die betrokke onderwysinstelling, die gedagte van die formele identiteit ver weg skyn te staan van die daaglikse praktiese, organisatoriese en onderwyskeuses van die onderriggewers. Die dokumente aangaande die formele identiteit of karakter (soos die visie, missie en beleidsdokumente van die Universiteit en die Fakulteit) laat die akademiese personeellid "smal en deduktief dink", terwyl die primêre belangstelling van die akademiese personeellid behoort te lê by die induktiewe redenering daaroor. In laasgenoemde sin is dit breër georiënteer as die formele besinning.

\section{Aanbevelings}

Op grond van die ondersoek kan die volgende metodologiese wenke aanbeveel word vir soortgelyke toekomstige ondersoeke in onderwysinstellings:

- Daar behoort 'n kommunikasiestrategie uitgewerk te word in terme waarvan die belangrikste beleidsdokumente van die onderwysinstelling pertinent onder almal wat daar werksaam is se aandag gebring word. Die bestuursimplikasies van sekere aspekte van hierdie dokumente moet veral onder almal se aandag gebring word. Die rasionaal van die 'n navorsingsprojek sal ook onder meer verduidelik moet word. Dit het in hierdie projek geblyk dat skriftelike kommunikasie nie optimaal gewerk het nie, ook nie versoeke om toeligtingsvergaderings by te woon nie. Daar sal dalk gebruik gemaak moet word van formele vergaderings om die rasionaal en die belangrikheid van die projek te verduidelik. Vraelyste (indien van toepassing) moet dan in sodanige vergaderings voltooi word.

- Daar is bedenkings oor ' $n$ poging om iets so abstrak as die praktykmaking van die lewensvisie meetbaar te maak en te versyfer. Hierdie kommer is deur respondente met die navorsers gedeel in persoonlike gesprekke. Dit is ook implisiet te kenne gegee deur die beduidende aantal akademiese personeellede 
wat nie aan die projek deelgeneem het nie, of nie daaraan wou deelneem nie. Verdere gesprekke moet gevoer word of hierdie soort ondersoeke wel hulle doel dien, en of daar nie aan alternatiewe maniere gedink moet word om die praktykmaking (belewing) van akademiese personeel se lewensvisie te beoordeel nie. Sodanige beoordeling kan byvoorbeeld geskied deur hulle studiegidse en handboeke te ontleed, of deur klasbesoeke en onderhoude.

- Ondersoeke soos hierdie moet verkieslik kwalitatief van aard wees. Lewensvisie en beleefde identiteit is omvattende en onvermydelik vae teoretiese konstrukte, sodat dit nie net moeilik is om te operasionaliseer nie, maar ook uiters moeilik om te meet met enige skaal wat kwantitatief sin maak. Vir hierdie doel kan byvoorbeeld gebruik gemaak word van die vraelys getiteld: Vrae met die oog op beoordeling van werksuitsette van bestuurshoofde (viserektore, dekane en direkteure) (PU vir CHO, 2002). Met hierdie instrument kan bestuurshoofde deur middel van doelgerigte vrae vasstel in welke mate die akademiese personeel onder hulle toesig inderdaad tot be-leefde lewensvisie kom.

- Voordat 'n ondersoek plaasvind, behoort daar eers 'n identiteitsberaad in die onderwysinstelling plaas te vind. Refleksie oor die identiteit van die onderwysinstelling moet by hierdie geleentheid nie by abstraksies begin nie. Dit moet begin waar die akademiese personeel en die studente die alledaagse praktyk as sin- of betekenisvol ervaar. Die beraad moet dus begrond wees in die alledaagse praktyk van die werk. In dié proses moet aandag gegee word aan die lewensbeskoulike aspekte van die alledaagse werk. Die lewensvisie is trouens 'n dimensie van die een en ondeelbare werklikheid van akademiese personeel se werk. Die beraad moet nie net duidelik gekontekstualiseerd wees nie, maar dit moet ook struktureel verankerd wees in die beleidsraamwerk van die onderwysinstelling (deel van die kwaliteitsorg), en dit moet die biografieë en die individuele interpretasies van al die betrokkenes in ag neem.

- Voordat 'n ondersoek plaasvind, moet daar eers intern in die onderwysinstelling ' $n$ omvattende en diepgaande besinning plaasvind - 'n besinning oor die sogenaamde "kloof" wat bestaan tussen enersyds wat verstaan word as die formele lewensbeskoulike identiteit van die instelling (hoe dit tot stand gekom het en hoe dit verstaan word), en die beleefde of gekontekstualiseerde lewensbeskoulike identiteit van die individuele 
akademiese personeellede. Dit kom tot uitdrukking in elkeen se professionele praktyk in die alledaagse omgewing.

- Die praktykmaking van die lewensvisie is maar die eerste stap. Dit moet opgevolg word deur toerusting vir die praktykmaking van ander fasette van grondslaestudies of -ondersoeke. Hieronder tel filosofiese grondslae-, vakfilosofie- en wetenskapsfilosofiese ondersoeke in die akademiese personeellid se betrokke dissipline. Die mate van welslae wat in die beoefening van hierdie vaardighede bereik word, moet ook op gepaste wyse gemeet word.

\section{Slotopmerking}

Hierdie projek het enersyds getoon dat akademiese personeellede van die betrokke Fakulteit Opvoedkunde dit erns maak met die praktykmaking van hulle lewensvisie. Dit het ook getoon dat daar ruimte vir verbetering in hierdie faset van hulle werksaamhede is. Die kwantifisering en meting van die lewensvisie is uit die staanspoor in die wiele gery deur ernstige metodologiese vraagstukke. Hierdie struikelblokke was van sodanige aard dat daar na alternatiewe, meer kwalitatiewe maniere van ondersoek, gesoek moes word om die "meting" of evaluering te doen.

Nuwere verwikkelinge op die terrein van die wetenskapsfilosofie toon dat dit deesdae tot die normale of gewone dagtaak van die wetenskaplike geag word om ook aandag aan die grondslae en vakfilosofiese aspekte (die sogenaamde dieptelae) van die wetenskap te gee. 'n Akademiese personeellid wat hierdie dieptelae self nie kan ondersoek en beoordeel nie, en die evaluering en kritiek daarvan aan professionele vakfilosowe oorlaat, kan nie meer as 'n goed-funksionerende wetenskaplike beskou word nie. Die wetenskaplike resultate wat hy/sy lewer kom ook onder verdenking, omdat sodanige personeel hierdie onmisbare dimensie van hulle werk oor die hoof sien of bloot miskyk.

Die bestuurders van 'n akademiese instelling soos ' $n$ universiteit sal hulle taak versuim as hulle nie volhard om daarop aan te dring dat die wetenskaplikes onder hulle toesig hulle voortdurend toelê op sulke grondslae-ondersoeke nie. Hierdie ondersoeke sal egter nie, soos wat byvoorbeeld vóór 1996 die geval was, binne 'n bepaalde lewensbeskoulike denkraamwerk, soos die reformatoriese, kan geskied nie. Die akademiese personeel van die toekoms sal opgelei moet word om te verstaan hoe 'n teoretiese en voorteoretiese denkraamwerk gebou kan word, en hoe sodanige raamwerk in die 
praktyk werk, toegepas en gemeet kan word. Deur hierdie vaardigheid te bemeester, dra akademiese personeel by tot hulle eie be-leefde lewensbeskoulike identiteit in hulle alledaagse akademiese praktyk. Hierdie be-lewing sal egter ook op gepaste wyse gemeet moet kan word.

\section{Geraadpleegde bronne}

BAKKER, C.B. 2004. Demasqué van het christelijk onderwijs: over onzin en zin van een adjectief. Utrecht: Faculteit Godgeleerdheid, Universiteit van Utrecht. (Utrechtse Theologische Reeks, deel 46.)

BREAKWELL, G.M., HAMMOND, S. \& FIFE-SCHAW, C. 1995. Research methods in psychology. London: Sage.

COLSON, C. 2001. The Christian in today's culture. Wheaton: Tyndale House.

DE MUYNCK, A. 2004. Werkplan lectoraat: onderwijs en identiteit. Gouda: Christelijke Hogeschool De Driestar.

DU PLESSIS, S.J.P. 1993. Handboek vir dosente. Potchefstroom: Akademiese Steundienste.

FRANCIS, L.J. 1984. Teenagers and the church: a profile of church-going youth in the 1980's. London: Culham Institute.

FRANCIS, L.J. 1985. Christian belief inventory. London: Culham Institute.

HOEKSEMA, K. 1992. ... dat toekomst heeft: over veranderingen in het levensbeschouwelijk karakter van de protestants-christelijke richting in ons onderwijsbestel. (In Van den Berg, J.S., red. Een onderwijsbestel met toekomst ... Amersfoort: Unie voor Christelijk onderwys. p.189-210.)

JAEGER, R.M. 1988. Complementary methods for research in education. Washington: American Educational Research Association.

KLINK, A. 1992. Pluriformiteit in de toekomst: over verlegenheden en gelegenheden in het maatschappelijk middenveld. (In Van den Berg, J.S., red. Een onderwijsbestel met toekomst ... Amersfoort: Unie voor Christelijk onderwys. p.175-188.)

LAMBERT, I.P.M. 1997. Thinking with the heart: educating emotional intelligence in children. (In Lambert, I. \& Mitchell, S. The crumbling walls of certainty. Sydney: Centre for the Study of Australian Christianity. p.154169.)

LEEDY, P.D. \& ORMROD, J.E. 2001. Practical research: planning and design. Upper Saddle River: Merrill-Prentice Hall.

MIDDLETON, J.R. \& WALSH, B.J. 1995. Truth is stranger than it used to be. Downers Grove: InterVarsity.

ODENDAL, F.F., SCHOONEES, P.C., SWANEPOEL, C.J, DU TOIT, S.J. \& BOOYSEN, C.M. 1997. Verklarende handwoordeboek van die Afrikaanse taal. Midrand: Perskor.

PATTERSON, R.F. 1990. The Greenwich English dictionary. London: Greenwich Editions.

POTGIETER, P.J.J.S. 2002. Vakfilosofie en grondslaestudie in die fakulteite en skole. Werksdokument: Sentrum vir Geloof en Wetenskap, PU vir $\mathrm{CHO}$.

PROCTER, P. 2002. Cambridge international dictionary of English. Cambridge: Cambridge University Press. 
PU VIR CHO. 2001. Na voltooiing van sy of haar studie aan die PU vir CHO sal die student afhangende van die vlak en duur van die studie, oor die volgende beskik. Beleidsdokument goedgekeur deur die Senaat. Potchefstroom.

PU VIR CHO. 2002. Visie en strategiese raamwerk 2002-2007. Potchefstroom, 24 Mei.

PU VIR CHO. 2003. Ethos and values. Deel van die nuusbrief van die Raad, uitgereik na die vergadering van die Raad by die Vaaldriehoekkampus. Potchefstroom, 10 April.

PUDLAS, K.A. 1997. Exceptionality in a communal context. (In Lambert, I. \& Mitchell, S. 1997. The crumbling walls of certainty. Sydney: Centre for the Study of Australian Christianity. p.170-183.)

RIJKEN-HOEVENS, A.L. S.a. Er zijn nog katechisanten ... Rapport nr. 9. Amsterdam: Instituut vir Praktiese Teologie, Universiteit van Amsterdam.

STURM, J., GROENENDIJK, L., KRUITHOF, B. \& RENS, J. 1998. Educational pluralism - a historical study of so-called "pillarization" in the Netherlands, including comparison with some developments in South African education. Comparative Education, 34(3):281-297.

TALJAARD, J.A.L. 1976. Polished lenses. Potchefstroom: Pro Rege.

VAN DER KOOY, R. 2004. Drie wonderwerke. Die Gereformeerde Vroueblad, 58(11):9.

VAN DER WALT, B.J. 1994. The liberating message. Potchefstroom: Institute for Reformational Studies. (Series F.)

VAN DER WALT, B.J. 2001. Shaping a radical Biblical worldview. Woord en Daad, 377:13.

VAN DRIEL, L. \& KOLE, I.A. 1987. Bij-tijds leren geloven: verkenning van het educatief climaat in een drietal kerkelijke gemeenten. Kampen: Kok.

WEHMEIER, S. 2002. Oxford advanced learner's dictionary. Oxford: Oxford University Press.

\section{Kernbegrippe:}

kwalitatiewe en kwantitatiewe ondersoekmetodes

lewensvisie

praktykmaking van die lewensvisie

reformatoriese denkraamwerk

\section{Key concepts:}

life-concept

life-concept in practice

quantitative and qualitative research methods

reformational frame of reference 
Metodologiese waarnemings by die meting van die beleefde lewensbeskoulike ... 